\title{
Team-Based Learning Theory Applied to Engineering Education: A System- atic Review of Literature
}

\section{Mr. Homero Gregorio Murzi, Virginia Polytechnic Institute and State University}

Homero is currently a PhD Student and Graduate Teaching Assistant in the Department of Engineering Education at Virginia Polytechnic Institute and State University. He is also an assistant professor in the Industrial Engineering department at the National University of Tachira in Venezuela. He holds a Bachelor and Master degree in Industrial Engineering from the National University of Tachira in Venezuela and a Master in Business Administration from Temple University. Homero was member of the Fulbright program from 2011 to 2013.

Homero's current research interests are in active learning pedagogies, cultural differences, teamwork, and entrepreneurship education. 


\section{Team-Based Learning Theory Applied to Engineering Education: A Systematic Review of Literature}

\section{Introduction}

The Accreditation Board for Engineering and Technology (ABET), in accordance with industry and academic leaders, are demanding that engineering schools produce engineers who are problem solvers, creative thinkers, and able to work effectively in groups [1]. Research done by Seely [2] and the American Society for Engineering Education (ASEE) [3] assert that improving teaching practices is necessary to help students develop those skills. The authors emphasize the importance of collaborative teaching strategies in the development of future engineers. Similarly, a report from the Executive Office of the President's Council of Advisors on Science and Technology [4] recommended the incorporation of active learning in engineering education. Several authors have demonstrated the benefits of active learning over lecture to improve students' learning and retention, but it has not yet been proven that active learning promotes creative thinking and teamwork skills. However, Terenzini, Cabrera [1] assert that collaborative learning can be considered an instructional strategy that can promote those skills. In addition, Seely [2] argues that in the need for change the engineering education field has evolved over time, moving from being focused on STEM and engineering science to add emphasis in how engineers should learn and acquire the skills desired by industry. This evolution, according to the author, requires that we implement research-based teaching strategies like active learning.

Active learning has been studied by several authors with demonstrated benefits in students, especially in engineering education. Several types of active learning strategies have been developed over time. Team-based learning (TBL) is considered by many authors to be any type of active learning that involves teams; however in this research TBL is considered a specific type of active learning. TBL is defined by Michaelsen, Knight [5] as an instructional strategy based on the development of high levels of team cohesiveness in students' learning groups, resulting in a wide variety of positive learning outcomes. Gallegos and Peeters [6] argue that just placing participants into groups does not automatically develop teamwork skills; thus an adequate model is required to develop those skills. According to Freeman [7], TBL involves students working intensively in small groups that are transformed into effective learning teams. The theory developed by Michaelsen, Knight [5] is based on students being able to transform into effective learning teams that develop teamwork skills in addition to traditional learning outcomes. In addition, authors like Haidet, Levine [8], Krishnan and Rama [9], Michaelsen, Parmelee [10], and Vasan, DeFouw [11] have done research in the medical education field focusing on TBL as an instructional strategy and have demonstrated favorable results in student learning outcomes. It may be prudent to consider this research in the engineering education field since medical students have similar desired outcomes as engineering students, like teamwork skills, problem-solving skills, and creative thinking [5]. As in medical education, TBL can be implemented in undergraduate engineering classrooms to promote creative thinking and teamwork, skills that are desired by industry, ABET, and the National Academy of Engineering [1, 12, 13]. 
In the effort to identify successful strategies to promote those skills, Prince [14] did an intensive literature review on active learning in engineering education. He showed examples of how active learning strategies generated positive results. In this review, however, TBL is not mentioned. In addition, Borrego, Froyd [15], in their study of learning beliefs about pedagogies in engineering science courses, listed fifteen different researchbased instructional strategies used in engineering education. Again, TBL was not included. In this case, similar to others presented by Michaelsen, Knight [5], TBL tends to be confused with cooperative learning since both promote individual accountability; however, TBL differentiates from cooperative learning because the teams formed in a TBL environment last for an entire semester and students are accountable both individually and as a team [5]. Thus there is a gap in engineering education research regarding implementation of TBL as an active learning strategy, since in most cases TBL is omitted in research discussing active learning. Furthermore, authors like Borrego, Froyd [15] and Prince and Felder [16] argue that research-based instruction strategies are not implemented as expected in engineering education. The authors suggest that research has proven the positive impact of different innovative teaching techniques, but that most courses in engineering programs continue to use the same teaching strategies that have been implemented for decades. The results of the research are not being implemented broadly; instead, traditional methods such as those discussed by Terenzini, Cabrera [1] and Demetry and Groccia [17] are typically found in most of the programs.

The purpose of this systematic review is to demonstrate the relevance of team-based learning in engineering education by surveying published research that investigates TBL as an active learning strategy. In addition the research will serve as a reference to identify misconceptions and to establish differences between cooperative, collaborative, problembased, project-based, and team-based learning as defined in the field. Finally, further implications for practice and future directions for research are identified.

\section{Methods}

The research method was a systematic review of research articles. Following systematic review procedures proposed by Gough, Oliver [18], the goal of the search was to identify a representative set of articles describing the use of active learning in engineering education, specifically focused on the use of TBL. The search was done simultaneously using two journal article databases: The Journal of Engineering Education and Engineering Village. The second database provided coverage of the primary journals in engineering and science education. Using the search terms "active learning," "teaching," "learning," and "teambased learning" in any field, the searched was focused on articles published in peerreviewed journals between January 1993 and December 2013. A 20-year period was selected intentionally in order to include relevant work related to cooperative learning done in the late 90's, and to achieve saturation. In the initial search 49 articles were found. Analyzing the full text of every article refined the search. The final articles were chosen for demonstrating all the following selection criteria:

1. The research must have used a type of active learning in the theoretical framework.

2. The research was focused on improving student learning in the engineering education field.

3. The research focused on developing engineering skills desired by industry with the implementation of innovative teaching strategies. 
In addition some articles were excluded due to misconceptions on the use of what active learning is. Other articles mentioned some of the proposed criteria in the abstracts; however in the full paper there was no evidence of such affirmations so they were excluded as well. After considering the criteria selection and excluding the papers mentioned before, a final result of 28 articles qualified for the study. Every paper was read twice and an excel file with relevant information about every article was created that included authors, summary, research objectives, theoretical framework, main findings, and relevant literature. Using literature reviews from separate articles, a comprehensive literature review was developed about active learning and team-based learning. A peer-review process was implemented after initial findings were obtained that allowed to make adjustments and to minimize the researcher bias.

\section{Discussion of Findings}

After an extensive analysis based on the literature review it was possible to determine that TBL is similar to several types of group-based pedagogies being used in engineering education, such as collaborative or cooperative learning [14]. However, TBL has specific characteristics that can differentiate it as a unique instructional strategy not very common in the engineering education field. Table 1 lists the main characteristics and differences of different types of active learning including TBL. Some of the similarities include: (i) involvement of students in teams, (ii) a project is developed, and (iii) the instructor has a key role in the process. The main difference between TBL and other instructional strategies is the focus on cohesiveness and development of teamwork skills. In PBL, for example, the focus is in solving a problem and developing problem-solving skills, while in TBL the final outcome is not as important as the process [19]. In collaborative learning the focus is on the use of complementary skills to solve a small activity, and in cooperative learning the use of cooperative skills to solve a long-term project; whereas in TBL the focus is beyond complementary or cooperative skills [20,21]. For example, TBL focuses on developing cohesiveness and synergy, and the strategy is implemented during an entire semester and on small activities and long-term projects at the same time. In addition, considering the positive outcomes in medical education and the similarities between expectations of engineering students and medical students, TBL may have positive outcomes in engineering education as well.

TBL is considered a type of active learning that not only generates knowledge of content but also develops teamwork skills because of the settings of the classroom. Every type of active learning is considered to promote desired outcomes in engineering education and TBL is recognized for developing those outcomes. Relevant concepts regarding the review will be explained in detail.

Active learning

Prince [14] intensive literature review on active learning in engineering education shows research done in the engineering education field where several types of active learning strategies were implemented with positive results. According to Bonwell and Eison [22] active learning is considered any instructional method that engages students in the learning process. Active learning is presented in several articles as the opposite of a traditional lecture because students reflect about what they are doing after engaging in several learning 
activities introduced in the classroom [1, 14, 16, 23-25]. In contrast, students in traditional lecture pedagogies receive information from the lecturer and their participation and engagement is minimal. As Smith, Sheppard [26] express: "students learn more when intensely involved in educational process and are encouraged to apply their knowledge in many situations" (p.87). According to Bonwell and Eison [22], the amount of information retained by students declines considerably after ten minutes of listening, so traditional instructional strategies may not be effective, specially in engineering education. Also, the reflection promoted in active learning has been proven to be more effective in engineering students than other educational strategies. By actively participating they have been able to obtain the desired learning outcomes offering itself as a more effective strategy in engineering education $[1,14,21,27,28]$.

According to Bonwell and Eison [22], active learning involves students doing things and reflecting about the things they are doing in order to acquire knowledge. The authors explain that active learning is a process where the students need to engage in different activities beyond passive listening. The focus of the teaching strategies is in the development of skills rather than in information transmission; therefore, motivation increases. There are several types of active learning instructional strategies that will be defined in the following paragraphs.

Prince (2004) defines different types of active learning. Collaborative learning refers to students working together in small groups in order to achieve a common goal. The emphasis is on student interactions in order to develop knowledge rather than individual interpretations. According to Bruffee [29], collaborative learning goals are to "help people to work together on substantive issues" (p.16). The evaluation of the outcomes focuses on the individual ability that the student develops by working together in groups and is demonstrated in a final product, not in the group processes. The author also argues that collaborative learning shifts the focus of individual competition in a classroom to group competition. According to Newstetter [30], in collaborative learning, teams work on a project that requires team members' collaboration. Therefore students will group in teams with other members that may have different skills. The major disadvantage of collaborative learning is the lack of individual accountability. Teachers evaluate groups based on the general outcome but are not close enough to understand or evaluate group interactions [29]. As a consequence, the undesired phenomenon of social loafing is presented with frequency. In order to avoid free riders, cooperative learning strategies may be implemented [16].

Cooperative learning is also considered a group instructional strategy as students achieve common goals. According to Kagan and Kagan [31] the principles in cooperative learning are (i) positive interdependence, (ii) individual accountability, (iii) simultaneous interactions, and (iv) equal participation. Cooperative learning tends to be confused with collaborative learning and there is a lot of controversy regarding its differences. In collaborative learning, students are assessed in groups, whereas cooperative learning focuses on the individual assessment of students with the instructor making a number of pre-instructional decisions [32]. Every group member in cooperative learning is rewarded based on the quality of the final product [33]. The concept of interdependence must be explained to students, and the instructor will constantly intervene to help students with tasks, interpersonal or group skills. The focus is on the incentives obtained by cooperating 
with each other to promote learning. Another difference between cooperative and collaborative learning according to Kagan and Kagan [31] is that cooperative learning requires simultaneous interaction between the students and leadership roles must rotate between the team members. In collaborative learning, students can work separately and compile their work at the end. Also in collaborative learning team members' roles do not change. Keyser [34] affirms that most of the active learning techniques are easier to apply and may take less class time, while cooperative learning requires more previous-class planning and the activities tend to last for the entire class time. In order to adequately implement a cooperative learning strategy, it is necessary to assign roles to every team member. The roles will vary frequently since the teams will change every class. Pimmel [35] affirms, "students learn better when working together than they do alone" (p.415). Cooperative learning is considered to be a formalized active learning structure; however not every active learning strategy is considered to be cooperative [36].

Problem-based learning (PBL) is another instructional method of active learning. Students receive relevant problems to solve during a class or an entire semester. According to Prince and Felder [16], students are confronted with open-ended, ill-structured, authentic problems that are similar to real world situations and work in teams that have to identify learning needs to solve the problem and develop a viable solution. The students receive few instructions to solve the problem, the instructor works as a facilitator rather than as a key source of information. The participants are involved in a self-directed and contextual environment that promotes learning. Sometimes PBL includes some combinations of collaborative and cooperative learning (Prince, 2004). A problem-based learning instructional strategy has several steps. Naming is the identification of main issues in the problem. Framing is considered to be the establishment of the limits of the problem. Moving is considered the experimental action taken to solve the problem, and reflecting is evaluating and criticizing the move. The learning will be obtained after this frame is fully developed [37]. In addition, Roselli and Brophy [38] state that a PBL environment needs to be student centered and must occur in small groups with the tutor acting as a facilitator. The role of the facilitator is to introduce the concepts and the problem-solving skills required to solve the problem. In PBL new information needs to be acquired with self-directed learning.

A similar instructional method that is commonly confused with PBL is Project-based learning. Prince and Felder [16] define project-based learning as a strategy that always begins with an assignment that involves a group of students into a series of tasks necessary to generate a final outcome. The outcome can be a product, a design, a model, a device, a program, or a simulation. The main difference with PBL is that in project-based learning the instructor gives several instructions and directs the students in the different stages of the project [19]. The guidance is considered necessary in order to maintain the relevance of the project with the course objectives and desired student outcomes.

Several authors consider TBL as a type of active learning. However, TBL is not mentioned in the intensive literature review done by Prince (2004). In addition, Borrego, Froyd [15] in their study of learning beliefs about pedagogies in engineering science courses, mentioned fifteen different research-based instructional strategies used in engineering education and TBL is not included as a research-based instructional strategy. Furthermore some authors use the term "team-based learning" as synonymous with collaborative learning. Although 
several collaborative learning, cooperative learning, problem based learning, and project based learning strategies include team activities, and TBL shares several principles of collaborative and cooperative learning, TBL is considered to be a specific instructional strategy that focuses on the development of cohesiveness and teamwork skills as explained on Table 1. TBL will be explained in detail in order to understand its uniqueness.

Team-based learning

According to Michaelsen, Knight [5] TBL is an instructional method based on the effective interaction of teams. The main difference of TBL in contrast to traditional lecture type strategies is the way concepts are understood. In traditional courses, the learning objective is to understand concepts. The learning objective in TBL is to build knowledge from the experiences and to develop cohesiveness and teamwork skills at the same time. In TBL, students are organized in effective teams and have the opportunity to practice those course concepts. The roles of students and teachers are also different. The teachers in a traditional environment are facilitators of information. In TBL, the teacher role is to guarantee the knowledge is being obtained but also to promote the synergy necessary to develop teamwork skills. The instructor is responsible for setting the stage of the problem, interacting with the students, designing effective activities, projects, and assessments that help promote effective teamwork, managing effective teams, and ensuring that students are relating the teamwork to the learning of the class objectives and developing teamwork skills. The students' role in a traditional environment is to receive and process information, with little or no participation. In TBL the student is responsible for the construction of knowledge, participation in every activity, commitment to the team, and preparation in order to contribute to the team dynamics. Michaelsen, Knight [5] argue that TBL effectiveness as an instructional strategy is based entirely in the fact that it "nurtures the development of high levels of group cohesiveness that, in turn, results in a wide variety of other positive outcomes" (p. 27).

According to Michaelsen, Knight [5], TBL has four principles that make it different from other types of collaborative learning strategies. First, teams must be properly formed and managed. This includes the creation of small teams (four or five participants) that will last for the entire course to minimize barriers that could impede cohesiveness. In addition, participants should be carefully selected to guarantee similar contributions to the assignments from different team members. The instructor also needs to develop assignments that are manageable but challenging enough to require participation of all team members in order to develop learning.

Second, students must be accountable for their individual and group work, with individual accountability evaluated by the instructor and the other team members. The instructor will be required to assess and reward different types of student behaviors. Students should understand that the quality of the work has positive or negative impact on the course grade. Students will be accountable individually for preparation for every class, and the team will be accountable for the interaction and the results of assignments. In addition, team members will evaluate each other. The instructor should supervise students to ensure that they have productive interactions to ensure team cohesiveness. 
Third, group assignments must promote both learning and team development. Effective assignments will ensure not only the development of teamwork skills but also will minimize the main problems of teamwork, like social loafing or miscommunication. Michaelsen, Knight [5] argue that it is very important to ensure that the assignments truly require team interaction in order to be solved. It is also recommended to avoid tasks that can be easily divided by team members.

Finally, students must have frequent and timely performance feedback based not only on the solution of the activities, but also in the team interactions and processes required to obtain the learning outcomes. Appropriate feedback will not only help students obtaining the required knowledge and skills, but also will help with the supervision of the development of teamwork skills. Michaelsen, Knight [5] argues that feedback should be immediate, frequent and discriminatory. The impact of positive feedback is greater when it is done as a continuous process in every class. Another benefit is that it helps students to identify between good and bad team decisions, and to select effective strategies to achieve team goals.

Michaelsen, Knight [5] explain that working in teams, even casually, can generate benefits that are not obtained with individuals working in passive roles. Katzenbach and Smith [39] explain the difference between teams and working groups. They affirm that teams are "a small number of people with complementary skills who are committed to a common purpose, set of performance goals, and approach for which they hold themselves mutually accountable" (p.162). Alternatively, working groups refers to people working together to achieve a common goal. The main difference is in performance. In working groups, performance is obtained by the individual contributions of every member. For teams, performance is obtained by the sum of the individual work plus the collective work (synergy). It is necessary to develop work together between several members of the team resulting in positive outcomes that improve performance [39]. Michaelsen, Parmelee [10] explains that casual work in groups is considered to have better outcomes that working individually, however the authors emphasize that TBL generates important outcomes that are beyond the benefits obtained with occasional group activities or temporary teams in the classroom. Some of the benefits include: developing students' higher level cognitive skills in large classes, providing social support for at-risk students, promoting the development of interpersonal and team skills, and building and maintaining faculty members' enthusiasm for the teaching role.

As mentioned before, TBL has been successfully applied in the medical education field in recent years. Parmelee, Michaelsen [40] argue that TBL is very effective in the medical field because of the rapidly changing environment that requires fast adaptation of the future professionals to complex situations. Knowledge is expanding and changing constantly, and because of that complexity it is not viable to implement traditional teaching strategies since students no longer need to memorize everything. Since the engineering profession also require adaptation to rapid and constant changes in a growing field of knowledge and skills, the same logic may be used in order to promote TBL in engineering education.

In addition, Parmelee, Michaelsen [40] present several characteristics that make TBL a good fit for engineering education: the versatility of use, effective team formation, and out- 
of-class preparation. First, TBL can be implemented in small or large classes, making it applicable in different scenarios. Second, teams are carefully selected and they focus on the development of teamwork and communication skills that are necessary in future engineers. Since it is very important that every individual member comes prepared to contribute to the team activity, out of class preparation is required and it helps develop adequate studying techniques better preparing them for demanding professional work where they will need to prepare individually to contribute in high performance teams. According to Randolph [41], there are many positive opportunities for students when instructors redesign learning to an active, team-based approach.

Jeffries and Huggett [42] state that the more students and faculty use TBL the more comfortable they become with it. This comfort level means that students and instructors will spend less time familiarizing with the process and more time in preparation. In addition, the time in the classroom invested in content and its application increases. In order to succeed, TBL requires additional time invested by faculty. The quality of the student experience is related to the time that the instructor puts into the process. Also the more the students come to the sessions prepared, the more they will obtain from the class.

Based on this systematic review it is possible to conclude that team-based learning is considered to be a good fit in the engineering education field as an effective active learning strategy that may promote the desired skills for engineering students such as teamwork, creativity, problem-solving and communication. TBL has been successful in medical education, but based on the information presented in this study it should be beneficial to consider the implementation of this instructional strategy in engineering education. Therefore, it is recommended to follow the model developed by Michaelsen et al. [5]. In addition, there has been limited response by faculty members in engineering education to implement research-based instructional strategies, in most of the cases because there are no clear steps to implement active learning $[15,16]$. However, the model of TBL presented in the study is easy to implement step-by-step in any classroom setting.

\section{Limitations}

The main limitation of the study was the lack of information about TBL in the engineering education field. In addition, there is always a possibility that the perspectives and findings can be biased. However a peer-review process was conducted in order to identify possible misconceptions and to identify subjectivity to minimize that risk.

\section{Future implications}

The research results are a contribution to map recent research done in engineering education about instructional innovations. It also expands a theoretical framework of teambased learning to clarify possible misconceptions when applying the concept in practice. The research concluded with specific differences between several types of active learning: collaborative, cooperative, problem-based, project-based, and team-based learning.

Future research is planned to measure the impact of team-based learning in the promotion of creative thinking in engineering education. The experiment will have a control group in a traditional lecture-type setting and an experimental group in a team-based learning setting to identify if TBL has an impact on creative thinking, a desired skill in future engineers. 


\section{Acknowledgement}

This material is based upon work supported by the National Science Foundation under Grant No. 0846605. Any opinions, findings, and conclusions or recommendations expressed in this material are those of the author(s) and do not necessarily reflect the views of the National Science Foundation.

\section{Bibliography}

1. Terenzini, P.T., et al., Collaborative Learning vs. Lecture/Discussion: Students' Reported Learning Gains. Journal of Engineering Education, 2001. 90(1): p. 123-130.

2. Seely, B.E., The Other Re-engineering of Engineering Education, 1900-1965. Journal of Engineering Education, 1999. 88(3): p. 285 - 294.

3. American Society for Engineering Education (ASEE), Innovation with Impact: Creating a Culture for Scholarly and Systematic Innovation in Engineering Education. 2012, Author: Washington, DC.

4. Executive Office of the President President's Council of Advisors on Science and Technology, REPORT TO THE PRESIDENT ENGAGE TO EXCEL: PRODUCING ONE MILLION ADDITIONAL COLLEGE GRADUATES WITH DEGREES IN SCIENCE, TECHNOLOGY, ENGINEERING, AND MATHEMATICS. 2012, President's Council of Advisors of Science and Technology: Washington, DC.

5. Michaelsen, L., A. Knight, and D. Fink, Team-based learning: a transformative use of small groups. 2002: Greenwood publishing group.

6. Gallegos, P.J. and M. Peeters, A measure of teamwork perceptions for team-based learning. Currents in Pharmacy Teaching and Learning, 2011. 3(1): p. 30-35.

7. Freeman, M., To adopt or not to adopt innovation: A case study of team-based learning. The International Journal of Management Education, 2012. 10(3): p. 155-168.

8. Haidet, P., et al., Guidelines for reporting team-based learning activities in the medical and health sciences education literature. Academic Medicine, 2012. 87(3): p. 292-299.

9. Krishnan, K. and R. Rama, 7th College of Physicians lecture: The changing face of medicine, medicine: Past, present and future. Annals of the Academy of Medicine, Singapore, 2011. 40(4): p. 201.

10. Michaelsen, L., D. Parmelee, and K. McMahon, Team-based learning for health professions education: A guide to using small groups for improving learning. 2008: Stylus Publishing, LLC.

11. Vasan, N.S., D.O. DeFouw, and S. Compton, A survey of student perceptions of team - based learning in anatomy curriculum: Favorable views unrelated to grades. Anatomical sciences education, 2009. 2(4): p. 150-155.

12. McMasters, J.H. and N. Komerath. Boeing-University Relations-A Review and Prospects for the Future. in Proc. ASEE Annual Conf. \& Expo. 2005.

13. National Academy of Engineering, Educating the engineer of 2020: Visions of engineering in new century. 2004, Washington, DC: National Academies Press.

14. Prince, M., Does Active Learning Work? A Review of the Research. Journal of Engineering Education, 2004. 93(3): p. 223-231.

15. Borrego, M., et al., Influence of Engineering Instructors' Teaching and Learning Beliefs on Pedagogies in Engineering Science Courses, in International Journal of Engineering Education. 2013.

16. Prince, M. and R. Felder, Inductive teaching and learning methods: Definitions, comparisons, and research bases. Journal of Engineering Education, 2006. 95(2): p. 123-138.

17. Demetry, C. and J.E. Groccia, A comparative assessment of students' experiences in two instructional formats of an introductory materials science course. Journal of Engineering Education, 1997. 86(3): p. 203-210.

18. Gough, D., S. Oliver, and J. Thomas, An introduction to systematic reviews. 2012: Sage London. 
19. Kolmos, A. and E.d. Graaff, Problem-based and Project-based Learning in Engineering EducationMerging Models, in In. A. Johri \& B. Olds (Eds.), Cambridge Handbook on Engineerind Education Research (CHEER). In press.

20. Zhou, C., A. Kolmos, and J.D. Nielsen, A Problem and Project-Based Learning (PBL) Approach to Motivate Group Creativity in Engineering Education. International Journal of Engineering Education, 2012. 28(1): p. 3 - 16.

21. Stump, G.S., et al., Collaborative Learning in Engineering Students: Gender and Achievement. Journal of Engineering Education, 2011. 100(3): p. 475 - 497.

22. Bonwell, C.C. and J.A. Eison, Active learning: Creating excitement in the classroom. 1991: School of Education and Human Development, George Washington University Washington, DC.

23. Fink, L.D., S. Ambrose, and D. Wheeler, Becoming a professional engineering educator: A new role for a new era. Journal of Engineering Education, 2005. 94(1): p. 185-194.

24. Mehta, S.I., A method for instant assessment and active learning. Journal of Engineering Education, 1995. 84(3): p. 295-298.

25. Lamancusa, J.S., et al., 2006 Bernard M. Gordon Prize Lecture*: The Learning Factory: Industry Partnered Active Learning. Journal of Engineering Education, 2008. 97(1): p. 5-11.

26. Smith, K.A., et al., Pedagogies of engagement: Classroom - based practices. Journal of Engineering Education, 2005. 94(1): p. 87-101.

27. Hsiung, C.-M., The Effectiveness of Cooperative Learning. jounal of Engineering Education, 2012. 101(1): p. 119-137.

28. Felder, R.M. and R. Brent, Understanding student differences. Journal of engineering education, 2005. 94(1): p. 57-72.

29. Bruffee, K.A., Sharing our toys: Cooperative learning versus collaborative learning. Change: The Magazine of Higher Learning, 1995. 27(1): p. 12-18.

30. Newstetter, W.C., Of green monkeys and failed affordances: A case study of a mechanical engineering design course. Research in Engineering Design, 1998. 10(2): p. 118-128.

31. Kagan, S. and M. Kagan, The Structural Approach: Six Keys to Cooperative Learning, in Handbook of Cooperative Learning Methods, S. Sharan, Editor. 1994 Greenwood Press: Westport Connenicut. p. $115-133$.

32. Johnson, D., R. Johnson, and K. Smith, Cooperative Learning Returns to College: What evidence is there that it works? Change, 1998. 30(4): p. 26-35.

33. Nembhard, D., K. Yip, and A. Shtub, Comparing competitive and cooperative strategies for learning project management. Journal of Engineering Education, 2009. 98(2): p. 181-192.

34. Keyser, M.W., Active learning and cooperative learning: understanding the difference and using both styles effectively. Research Strategies, 2000. 17(1): p. 35-44.

35. Pimmel, R., Cooperative learning instructional activities in a capstone design course. Journal of Engineering Education, 2001. 90(3): p. 413-421.

36. Finelli, C.J., A. Klinger, and D.D. Budny, Strategies for Improving the Classroom Environment*. Journal of Engineering Education, 2001. 90(4): p. 491-497.

37. Nelson, W.A., Problem solving through design. New Directions for Teaching and Learning, 2003. 2003(95): p. 39-44.

38. Roselli, R.J. and S.P. Brophy, Effectiveness of Challenge - Based Instruction in Biomechanics. Journal of Engineering Education, 2006. 95(4): p. 311-324.

39. Katzenbach, J.R. and D.K. Smith, The discipline of teams. 1993: Harvard Business Press.

40. Parmelee, D., et al., Team-based learning: A practical guide: AMEE Guide No. 65. Medical Teacher, 2012. 34(5): p. e275-e287.

41. Randolph, G.B., Collaborative learning in the classroom: A writing across the curriculum approach. Journal of Engineering Education, 2000. 89(2): p. 119-122.

42. Jeffries, W.B. and K. Huggett, An Introduction to Medical Teaching. 2010, New York: Springer Dordrecht Heidelberg.

43. Gomez, E.A. and M. Bieber. Towards Active Team-Based Learning: An Online Instructional Strategy. in AMCIS 2005 Conference on Information Systems. 2005. Omaha, NE USA. 
Appendix: Table 1. Different types of active learning strategies

\begin{tabular}{|c|c|c|c|c|c|c|c|c|}
\hline $\begin{array}{c}\text { Active } \\
\text { Learning }\end{array}$ & Description & $\begin{array}{c}\text { Knowledge } \\
\text { obtained }\end{array}$ & $\begin{array}{l}\text { Expected } \\
\text { outcomes }\end{array}$ & $\begin{array}{c}\text { Base of } \\
\text { evaluation }\end{array}$ & Assessment & $\begin{array}{c}\text { Role of } \\
\text { instructor }\end{array}$ & $\begin{array}{c}\text { Previous } \\
\text { information }\end{array}$ & $\begin{array}{c}\text { Team } \\
\text { dynamics }\end{array}$ \\
\hline $\begin{array}{l}\text { Collaborative } \\
\text { Learning }\end{array}$ & $\begin{array}{l}\text { Small teams } \\
\text { work } \\
\text { together } \\
\text { common } \\
\text { goal } \\
{[14]}\end{array}$ & $\begin{array}{l}\text { By students } \\
\text { interactions } \\
{[14,15]}\end{array}$ & $\begin{array}{l}\text { Final } \\
\text { product } \\
{[15]}\end{array}$ & $\begin{array}{l}\text { Individuals } \\
\text { abilities } \\
\text { Quality of } \\
\text { the final } \\
\text { product } \\
{[16]}\end{array}$ & $\begin{array}{l}\text { Group based } \\
\text { on the final } \\
\text { outcome } \\
{[14,29]}\end{array}$ & $\begin{array}{l}\text { Promote } \\
\text { team } \\
\text { interactions, } \\
\text { support with } \\
\text { complementa } \\
\text { ry skills } \\
\text { information } \\
{[30]}\end{array}$ & $\begin{array}{l}\text { Concepts of } \\
\text { complementa } \\
\text { ry skills } \\
{[16,29]}\end{array}$ & $\begin{array}{l}\text { Complementary } \\
\text { skills of team } \\
\text { members. } \\
\text { Team for an } \\
\text { specific } \\
\text { activity, change } \\
\text { every class } \\
{[14,29,30]}\end{array}$ \\
\hline $\begin{array}{l}\text { Cooperative } \\
\text { Learning }\end{array}$ & $\begin{array}{l}\text { Small teams } \\
\text { working on a } \\
\text { common } \\
\text { goal } \\
{[14,15,32]}\end{array}$ & $\begin{array}{l}\text { By the } \\
\text { recognition } \\
\text { of the } \\
\text { incentives } \\
\text { obtained } \\
\text { from } \\
\text { students } \\
\text { cooperation } \\
{[31]}\end{array}$ & $\begin{array}{l}\text { Final } \\
\text { product } \\
\text { Developme } \\
\text { nt of } \\
\text { cooperative } \\
\text { skills } \\
{[14,15,32]}\end{array}$ & $\begin{array}{l}\text { Quality of } \\
\text { the final } \\
\text { product } \\
{[32,33,35]}\end{array}$ & $\begin{array}{l}\text { Individual } \\
\text { assessment } \\
\text { based on the } \\
\text { final } \\
\text { outcome } \\
{[14,31,32]}\end{array}$ & $\begin{array}{l}\text { Prepare } \\
\text { specific } \\
\text { assignments } \\
\text { previous to } \\
\text { class. } \\
\text { Intervene } \\
\text { constantly } \\
\text { helping } \\
\text { students with } \\
\text { tasks, } \\
\text { interpersonal } \\
\text { and group } \\
\text { interactions } \\
\text { [32] }\end{array}$ & $\begin{array}{l}\text { Concepts of } \\
\text { interdepende } \\
\text { ncy } \\
{[14,31,32]}\end{array}$ & $\begin{array}{l}\text { Interdependenc } \\
\text { y. } \\
\text { Every team } \\
\text { member is } \\
\text { assigned with a } \\
\text { role. } \\
\text { Teams and } \\
\text { roles change } \\
\text { every class } \\
{[14,31-33,35]}\end{array}$ \\
\hline $\begin{array}{l}\text { Problem- } \\
\text { based } \\
\text { learning }\end{array}$ & $\begin{array}{l}\text { Small teams } \\
\text { receiving a } \\
\text { problem to } \\
\text { be solved } \\
{[16]}\end{array}$ & $\begin{array}{l}\text { By } \\
\text { identifying } \\
\text { learning } \\
\text { needs to } \\
\text { solve the } \\
\text { problem } \\
\text { and } \\
\text { develop a } \\
\text { viable } \\
\text { solution } \\
{[14,16]}\end{array}$ & $\begin{array}{l}\text { Developme } \\
\text { nt of } \\
\text { problem- } \\
\text { solving and } \\
\text { communica } \\
\text { tion skills } \\
\text { Find the } \\
\text { solution to } \\
\text { a problem } \\
{[14,16]}\end{array}$ & $\begin{array}{l}\text { Quality of } \\
\text { the } \\
\text { problem- } \\
\text { solving } \\
\text { process and } \\
\text { the possible } \\
\text { alternative } \\
\text { solutions } \\
{[14,16]}\end{array}$ & $\begin{array}{l}\text { Team } \\
\text { assessment } \\
\text { based on the } \\
\text { process of } \\
\text { solving the } \\
\text { problem } \\
{[14,16,19 \text {, }} \\
37,38]\end{array}$ & $\begin{array}{l}\text { Facilitator } \\
\text { rather than } \\
\text { source of } \\
\text { information. } \\
{[14,16,19 \text {, }} \\
37,38]\end{array}$ & $\begin{array}{l}\text { Detailed } \\
\text { information } \\
\text { about the } \\
\text { expectations } \\
\text { is required } \\
{[14,16,20]}\end{array}$ & $\begin{array}{l}\text { Self directed } \\
\text { teams, } \\
\text { contextual } \\
\text { environment, } \\
\text { few instructions } \\
\text { and rules } \\
{[14,16,19,37,} \\
38]\end{array}$ \\
\hline $\begin{array}{l}\text { Project-based } \\
\text { learning }\end{array}$ & $\begin{array}{l}\text { An } \\
\text { assignment } \\
\text { that involves } \\
\text { a group of } \\
\text { students into } \\
\text { a series of } \\
\text { tasks } \\
\text { necessary to } \\
\text { generate a } \\
\text { final } \\
\text { outcome } \\
{[14]}\end{array}$ & $\begin{array}{l}\text { By } \\
\text { developing } \\
\text { the } \\
\text { different } \\
\text { phases of } \\
\text { the project } \\
\text { to solve a } \\
\text { problem } \\
{[14]}\end{array}$ & $\begin{array}{l}\text { Final } \\
\text { product, } \\
\text { design, } \\
\text { program or } \\
\text { simulation } \\
{[19]}\end{array}$ & $\begin{array}{l}\text { Quality of } \\
\text { the final } \\
\text { product } \\
{[19]}\end{array}$ & $\begin{array}{l}\text { Team } \\
\text { assessment } \\
\text { based on the } \\
\text { final } \\
\text { outcome } \\
{[16]}\end{array}$ & $\begin{array}{l}\text { Instructor } \\
\text { provides } \\
\text { several } \\
\text { instructions } \\
\text { and leads the } \\
\text { students to } \\
\text { achieve the } \\
\text { different } \\
\text { phases of the } \\
\text { project. } \\
{[15,16]}\end{array}$ & & $\begin{array}{l}\text { Instructor } \\
\text { indicates the } \\
\text { different tasks } \\
\text { the team needs } \\
\text { to solve. Self- } \\
\text { organized teams } \\
\text { and } \\
\text { responsibilities. } \\
\text { Teams can } \\
\text { change every } \\
\text { class or last the } \\
\text { entire semester } \\
{[16,19]}\end{array}$ \\
\hline $\begin{array}{l}\text { Team-based } \\
\text { learning }\end{array}$ & $\begin{array}{l}\text { Teams of } 5 \\
\text { students } \\
\text { interact } \\
\text { working in } \\
\text { every class } \\
\text { to learn the } \\
\text { topics. A } \\
\text { final } \\
\text { outcome is } \\
\text { optional } \\
{[5,10]}\end{array}$ & $\begin{array}{l}\text { By } \\
\text { participatio } \\
\mathrm{n}, \\
\text { commitmen } \\
\mathrm{t} \text { to the } \\
\text { team, } \\
\text { previous } \\
\text { preparation, } \\
\text { developme } \\
\text { nt of } \\
\text { teamwork } \\
\text { skills } \\
\text { knowledge } \\
\text { is } \\
\text { constructed } \\
{[5,40]}\end{array}$ & $\begin{array}{l}\text { Developme } \\
\text { nt of } \\
\text { teamwork } \\
\text { skills } \\
\text { Developme } \\
\text { nt of } \\
\text { communica } \\
\text { tion skills } \\
\text { Final } \\
\text { product } \\
{[5,42]}\end{array}$ & $\begin{array}{l}\text { Quality of } \\
\text { individual } \\
\text { contributio } \\
\text { ns and team } \\
\text { processes } \\
{[5,10]}\end{array}$ & $\begin{array}{l}\text { Individual } \\
\text { and team } \\
\text { assessment } \\
\text { based on the } \\
\text { team process } \\
\text { developed in } \\
\text { every class } \\
{[5,40,43]}\end{array}$ & $\begin{array}{l}\text { Set the } \\
\text { course } \\
\text { settings to } \\
\text { focus on } \\
\text { development } \\
\text { of teamwork } \\
\text { skills. } \\
\text { Supervising } \\
\text { that students } \\
\text { relate } \\
\text { teamwork to } \\
\text { the learning } \\
\text { of the class } \\
\text { objectives. } \\
{[5,8,40]}\end{array}$ & $\begin{array}{l}\text { The TBL } \\
\text { model is } \\
\text { explained, in } \\
\text { addition } \\
\text { students } \\
\text { need to } \\
\text { prepare } \\
\text { individually } \\
\text { before every } \\
\text { session. } \\
{[5,10,40]}\end{array}$ & $\begin{array}{l}\text { Individual } \\
\text { preparation } \\
\text { previous to } \\
\text { every class, } \\
\text { teamwork to } \\
\text { address every } \\
\text { topic of the } \\
\text { course, } \\
\text { semester-long } \\
\text { teams, focus on } \\
\text { the } \\
\text { development of } \\
\text { teamwork skills } \\
\text { and } \\
\text { cohesiveness } \\
{[5,8,10,40,} \\
41,43] \\
\end{array}$ \\
\hline
\end{tabular}

